\title{
Internalization of Ecopreneurship Values through the Development of Poetry Anthology in Primary School
}

\author{
Sani Aryanto ${ }^{1}$, Rahman $^{2}$, Tatat Hartati ${ }^{3}$, Nunuy Nurkaeti ${ }^{4}$,Zahara Tussoleha Rony ${ }^{5}$, \\ Suharjuddin ${ }^{6}$, Dindin Abdul Muiz Lidinillah ${ }^{7}$, Febi Junaidi ${ }^{8}$ \\ \{sani.aryanto@dsn.ubharajaya.ac.id ${ }^{1}$ \} \\ Pendidikan Guru Sekolah Dasar, Universitas Bhayangkara Jakarta Raya, 12550, Indonesia ${ }^{1,4,5,6}$ \\ Pendidikan Dasar, Universitas Pendidikan Indonesia, 40154, Indonesia ${ }^{2,3,7}$ \\ Pendidikan Bahasa Indonesia, Universitas Sebelas Maret, 57126, Indonesia ${ }^{8}$
}

\begin{abstract}
Covid-19 is an indicator of the ecological system imbalance. Indonesia is one of many countries affected by Covid-19 when there are many problems that occur todays. Based on the result of Global Competitive Index, there are three main problems in Indonesia: economic, environmental, and primary education. The ecopreneurship concept is considered as a solution to solve the problems faced by Indonesia. Thus, there needs to be a comprehensive effort to implement ecoprenuership concept in various fields. One of the interpretations of ecoprenuership concept in primary education sector can be implemented through Developing Poetry Anthology Based on Ecopreneurship Values. Therefore, this research aims to develop Poetry Anthology Based on Ecopreneurship Values to antisipative effort to face the main problems in Indonesia. The research method was a research and development (R\&D) involving lecturers, teachers, and students in collage and Primary School. This research described the process of designing poetry anthology and the result of trials proving the anthology can be used as an alternative teaching material in primary school in term of language, content, pedagogical characteristics, conformity to ecoprenuership concept, and layout or images. The results of this reserach are expected to provide benefits to various parties, especially primary school teachers in developing innovative and creative teaching materials.
\end{abstract}

Keywords: Ecopreneurship, poetry, covid-19

\section{Introduction}

The Covid-19 pandemic has an unexpected policy impact in every area [1][2]. Various efforts have been done and one of the curative efforts that began to be implemented is the implementation of the "New Normal" era to anticipate problems that often occur during the Covid-19 period, especially in the sector of economy, social, environment, and education [3]. Covid-19 should make Indonesians do a reflection because this disaster is strongly related to the behaviour of Indonesians who are not environmentally friendly. Although Indonesia is believed to have excellent demographic potential and is expected to experience the golden age in 2045 [4], the way Indonesia deals with this pandemic seems to clearly show that Indonesia should continue to improve and seek better preventive and curative solutions to overcome problems that occur [5]. According to the Global Competitive Index, Indonesia ranked 38 out of 139 countries. Considering the huge demographics of Indonesia, this achievement was far from excellent. Indonesia is currently facing three types of problems, namely, (a) economic problems 
caused by low productive behaviour and high consumptive behaviour; (b) environmental problems that lead to poor health system; and (c) educational problems, especially related to segregation and lack of inclusive education issues [6][7]. These three problems should be solved first in this Covid-19 pandemic. Moreover, Indonesia is believed to have a potential demographic with the population mostly coming from millennials or Gen Y. In Indonesia 2015, Gen-Y or the Millennial Generation amounted to about 137.9 million people, according to Central Statistics Agency [8][9].

Ecopreneurship is regarded as a solution that can be used to solve the three main problems faced by Indonesia todays. Conceptually, ecopreneurship is the integration of ecoliteracy and entrepreneurship concepts. The concept was first developed by Schaper who defines the ecopreneurship as a form of entrepreneurship that is environmentally friendly [10]-[12]. At first, the concept was implemented in the economic world and has not been massively adopted in various fields, including the field of education.

Every primary school teacher should be able to initiate an internalization of ecopreneurship values in all creative learning activities. One of the learning activities that could be chosen to internalize values and characters in students is poetry learning. Poetry is believed to be the appropriate method for internalizing humanitarian values and related to the nature of education that aims to humanize human [6]. Through poetry, children will be internalized events in their surrounding environment. Poetry provides a life experience meaning a child's experience is unearthed through his or her experience when reading poetry. In addition, literary texts teach characters without having to patronize. But unfortunately, the research and availability of children's literature reading materials in primary school is still limited let alone poetry containing the values of ecopreneurship. Therefore, the results of this study describe the process of developing an anthology of children's poetry based on ecopreneurship covering the stage of (1) prelimenary study; (2) design; (3) trials; and (4) validation, so that the anthology of poetry can actually be utilized by any primary school.

The results of this study are also expected to be a comprehensive effort in improving literacy and writing skill in primary schools. Moreover, literacy reading and writing in Indonesia is still relatively low and requires the attention of all the community, especially teachers in primary schools [13]-[15]. The results of this study are an alternative to the creation of useful teaching materials in primary school.

\section{Method}

This study is a research and development (R\&D) study with a model referring to the model proposed by Borg and Gall (1989) according to [9] adapted to the field of education. The main stages of this research in Figure 1. 


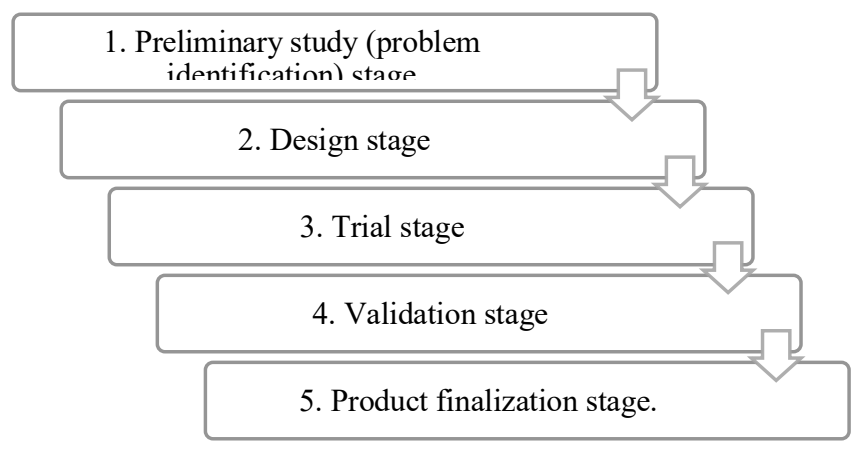

Fig.1. The Main Stages of Research.

The results describe the process of developing an anthology of children's poetry based on ecopreneurship covering the stage of (1) preliminary study; (2) design; (3) trials; and (4) validation, so that the anthology of poetry can actually be utilized by any primary school. The data then were analysed through the following four stages: (1) the collection of the relevant data in accordance with research variables (2) the presentation of the data collected (3) the reduction and cataloguing of the data (4) the conclusion drawing based on the results of valid and reliable data verification [9].

\section{Results and Discussion}

This research is one of the efforts to develop teaching materials of children's literature interpreted in the form of Anthology of Children's Poetry Based ecopreneurship with the theme/topic about Covid-19. The reason for the selection of covid-19 topic is expected to be one of anticipatory efforts to face the negative impact of the Covid-19 Pandemic so that the values of ecopreneurship internalized in each poem are expected to be the guideline of students in addressing various possible problems that occur today and future. Moreover, the values of ecopreneurship are believed to be the right step in preparing the Golden Generation in 2045 and are expected to accommodate three problems of Indonesia today, including the economy, environment, and basic education.

This research uses research and development (R\&D) design with a model that refers to the opinions of Borg and Gall (1989) tailored to the field of basic education and needs. There are four main stages performed in this study, including: (1) Prelimenary study stage; (2) design; (3) trials; and (4) validation. Here's an overview of the research that has been done.

\subsection{Preliminary Study}

There are two important stages performed in prelimenary study, including:

\section{The Literature Study}

The study of literature that researchers have interpreted through the search activities of relevant theories in the development of anthology of children's poetry based on ecopreneurship as a conceptual foundation to develop an anthology of poetry that is representative with the characteristics and needs of primary school students and relevant theories that have been collected by researchers include: (1) The basic framework of the concept of ecopreneurship; (2) 
internalization of ecoprenuership values to anticipate the disruptive era during covid-19 pandemic; (3) children's poetry.

\section{Previuos Research}

Some of relevant research to development of an anthology of children's poetry based on ecopreneurship has not been done. At first the concept of ecopreneurship existed only in economics and has not yet penetrated in the field of education, but the values contained in the concept of ecopreneurship are considered important to be taught in the context of education. Researchers conducted the study as a part of ecopreneurship concept framework in education. The concept of ecopreneurship began to be reviewed specifically in primary school [16], the study that had been done gives a concept of ecopreneurship although there has never been any research specifically on the development of teaching materials based on ecopreneurship. As for the development of teaching materials that Andriani has developed (2019) only discusses the concept of ecoliteration. Therefore, this study was conducted as an effort to develop teaching materials in the form of literary anthologies based on ecopreneurship in primary school that are considered never done by other researchers.

\subsection{Design}

\section{Formulating the Purpose of Book Development}

The anthology of poetry developed is aimed at grade IV students as a manifestation of the internalization of ecopreneurship values that are expected to support the thematic learning process in Grade IV Primary School Environmental Themes.

Here is a list of Basic Competencies selected and used in Theme 1 (Me and My Dreams) and Theme 3 (Caring for the Environment) based on the curriculum which is a reference to the development of an anthology of children's poetry based on ecoprenuership contained in Table 1.

Table 1. Basic Competencies

\begin{tabular}{|c|c|c|}
\hline \multicolumn{3}{|c|}{ Basic Competencies } \\
\hline Indonesian Language & Natural Sciences & Social Sciences \\
\hline $\begin{array}{l}\text { 1.2 Acknowledge and thank god } \\
\text { almighty for the existence of } \\
\text { environment and natural resources, } \\
\text { modern and traditional technological } \\
\text { tools, technological developments, } \\
\text { social, and social problems. } \\
\text { 2.4 Have concern for the environment } \\
\text { and natural resources through the } \\
\text { utilization of Indonesian language. } \\
3.6 \text { dig into the contents and mandate } \\
\text { of poems presented orally and written } \\
\text { for pleasure } \\
\text { 4.6 Write personal poems with proper } \\
\text { pronunciation, intonation, and } \\
\text { expression as self-expression. }\end{array}$ & $\begin{array}{l}\text { 1.1 Increasing his faith by realizing the } \\
\text { relationship of regularity and complexity } \\
\text { of nature and the universe to the greatness } \\
\text { of God who created it, and making it } \\
\text { happen in the practice of religious } \\
\text { teachings he embraced. } \\
2.1 \text { Demonstrate scientific behavior (being } \\
\text { curious; objective; honest; conscientious; } \\
\text { conscientious; diligent; caring; } \\
\text { responsible; open; and environmentally } \\
\text { caring) in daily activities as a form of } \\
\text { implementation of attitudes in conducting } \\
\text { scientific inquisiations and discussing } \\
3.7 \text { Describe the relationship between } \\
\text { natural resources and the environment, } \\
\text { technology, and society }\end{array}$ & $\begin{array}{l}\text { 3.5 Understanding } \\
\text { humans in the } \\
\text { dynamics of } \\
\text { interaction with } \\
\text { the natural, social, } \\
\text { cultural, and } \\
\text { economic } \\
\text { environments. }\end{array}$ \\
\hline
\end{tabular}


Based on these three basic concepts, the purpose of developing this poetry anthology is to provide alternative teaching materials through the internalization of ecopreneurship values in poetry. Moreover, the topics or themes created are based on contextual conditions related to the Covid-19 Pandemic Topic.

\section{Anthology Design/Prototype}

The design of an anthology of ecoprenuership-based poetry has reached $98 \%$ and has been tested limited and validated by expert judgement. The design of poetry is based on 18 values of ecopreneurship and in its development, the values of ecopreneurship internalized in this poetry anthology are each interpreted in at least two poems for each grade, so it is hoped that primary school students can find differences in grades in each of them and can benefit from the values highlighted to be condoed in daily behavior. One of examples of poems that have been composed in Table 2 .

Table 2. Poetry Based Ecopreneurship.

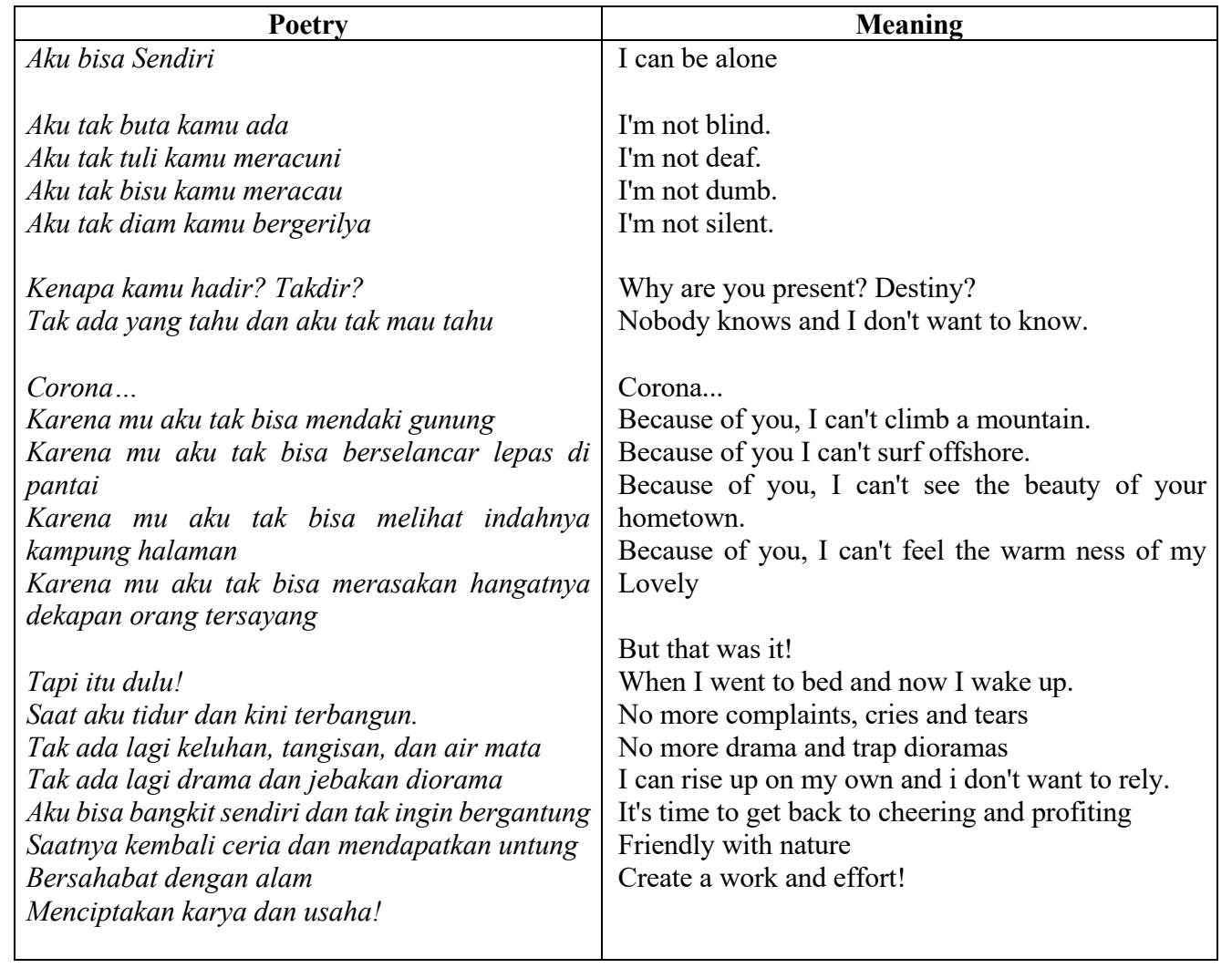

The design of the poem anthology above is based on aspects of language and the concept of ecopreneurship that is expected to be truly representative.

\subsection{Trial}


The trial was conducted through limited tests and extensive tests conducted at SDN Teluk Pucung 1 Bekasi City, initially trials will be conducted in two schools but due to the Covid-19 Pandemic not all schools can accept research activities even though both schools are fip ubhara jaya partner schools, without reducing the intent and purpose of the research amid the limited impact of Covid-19 trials conducted only at SDN Teluk Pucung 1 Bekasi city by engaging research subjects or respondents of teachers and students in grade IV of SDN Teluk Pucung 1 Bekasi City.

The trials conducted during this study were limited to 10 students. Based on the level of read ability and understanding in the anthology of poetry can be seen through Table 3.

Table 3. Student Limited Trial Results.

\begin{tabular}{|c|c|c|c|}
\hline \multirow{2}{*}{\multicolumn{2}{|c|}{ Indicator }} & \multicolumn{2}{|c|}{ Percentage } \\
\hline & & yes & No \\
\hline Content & $\begin{array}{l}\text { Poetry anthology illustrates themes } \\
\text { based on entrepreneurial values }\end{array}$ & $100 \%$ & $0 \%$ \\
\hline \multirow[t]{2}{*}{$\begin{array}{l}\text { Diction and } \\
\text { Language Style }\end{array}$} & $\begin{array}{l}\text { Poetry anthology uses easy-to- } \\
\text { understand words }\end{array}$ & $80 \%$ & $20 \%$ \\
\hline & $\begin{array}{l}\text { Poetry anthology pays attention to } \\
\text { rhymes and rhythms accordingly }\end{array}$ & $100 \%$ & $0 \%$ \\
\hline \multirow[t]{3}{*}{ Assessment } & Visual impressions & $100 \%$ & $0 \%$ \\
\hline & Auditive impressions & $90 \%$ & $10 \%$ \\
\hline & Tactile impressions & $70 \%$ & $30 \%$ \\
\hline $\begin{array}{l}\text { Meaning of The } \\
\text { Word }\end{array}$ & $\begin{array}{l}\text { Poetry anthologies create a broad and } \\
\text { unscpiteive wording that is rich in } \\
\text { emotional disclosure }\end{array}$ & $100 \%$ & $0 \%$ \\
\hline
\end{tabular}

The limited test results in Table 3 show students' responses to anthologies made in line with researchers' expectations, but these results should be retested in broader testing.

\subsection{Validation}

Validation is done through construct validation where the poetry anthology that has been tested is limited then validated by several validators who are experts in the field. The following construct validation results can be viewed in Table 4.

Tabel 4. The Result of Construct Validation.

\begin{tabular}{|c|c|}
\hline Aspects & \multicolumn{1}{c|}{ Description } \\
\hline Language and Content & $\begin{array}{l}\text { The language used in this anthology is considered to have represented the } \\
\text { characteristics of grade IV primary school students by describing several } \\
\text { characteristics, including: } \\
\text { 1.Language expression is simpler judging by the elements of diction, } \\
\text { structure, expression, and possible inclusion } \\
\text { 2.The language and depowering of various expressions, imagery and various } \\
\text { depictions is still limited to the reach of the child }\end{array}$
\end{tabular}




\begin{tabular}{|l|l|}
\hline & 3.The emotional aspect is always in line with the divorce of the senses \\
\hline $\begin{array}{l}\text { Ecoprenuership } \\
\text { Concept Conformity }\end{array}$ & $\begin{array}{l}\text { Each poem already represents 18 values of ecoprenuership, although each } \\
\text { value is manifested only in two poems. But every depiction of the value in each } \\
\text { poem is considered in accordance with the values of ecopreneurship. }\end{array}$ \\
\hline $\begin{array}{l}\text { Pedagogical } \\
\text { Characteristics/ } \\
\text { Children's Books }\end{array}$ & $\begin{array}{l}\text { Poetry anthology arranged deserves to be used as a supporting material for } \\
\text { thematic learning, especially for theme 1 and theme 3 }\end{array}$ \\
\hline $\begin{array}{l}\text { Illustrations } \\
\text { Layouts }\end{array}$ & $\begin{array}{l}\text { The layout, color selection, and illustration image in the cover already } \\
\text { illustrate the characteristics of Grade IV primary school children. }\end{array}$ \\
\hline
\end{tabular}

\section{Conclusion}

The development of a poetry anthology based on ecopreneurship that has been composed reached $98 \%$ and has been carried out a limited test process for teachers and students in SD Teluk Pucung 1 Bekasi City. The limited test results showed that the anthology developed was considered to represent the needs of elementary school students, this was confirmed through constructed validation from expert judgement which revealed that the anthology of poems composed already meets the elements of learning materials in elementary school from various aspects including: language, content, ecoprenuership concept conformity, pedagogical characteristics/ children's books, illustrations and layouts. The next step to improve the results of this study will be to conduct more extensive tests on teachers and students. Therefore, the results of this study are expected to be a reference for teachers and other researchers in developing grade-based teaching materials in primary school.

\section{References}

[1] F. Sanchis-Gomar, C. J. Lavie, M. R. Mehra, B. M. Henry, and G. Lippi, "Obesity and Outcomes in COVID-19: When an Epidemic and Pandemic Collide," Mayo Clin. Proc., 2020, doi: 10.1016/j.mayocp.2020.05.006.

[2] L. Fan, S. Jiang, X. Yang, Z. Wang, and C. Yang, "COVID-19 Drug Treatment in China," Curr. Pharmacol. Reports, pp. 1-9, 2020, doi: 10.1007/s40495-020-00218-5.

[3] B. Bikdeli et al., "COVID-19 and Thrombotic or Thromboembolic Disease: Implications for Prevention, Antithrombotic Therapy, and Follow-Up: JACC State-of-the-Art Review,” J. Am. Coll. Cardiol., vol. 75, no. 23, pp. 2950-2973, 2020, doi: 10.1016/j.jacc.2020.04.031.

[4] S. Aryanto, "The Implementation of Edupreneurship Based on Local Wisdom in Primary School as an Effort to Prepare Indonesian Golden Era," Educ. 21st Century Responding to Curr. Issues, pp. 787-793, 2016.

[5] A. Kiky, "Manajemen Resiko terhadap Black Swan Event Maret 2020 di Indonesia. Studi Kasus Efek Covid-19 Terhadap Pasar Modal Indonesia,” J. Bina Manaj., vol. 8, no. 2, pp. 90-105, 2020.

[6] S. Aryanto and A. Widiansyah, "Indonesian Journal of Primary Education Kreativitas dalam Pembuatan Sastra Anak Berbasis Ecopreneurship," vol. 3, no. 2, pp. 83-90, 2019.

[7] S. Aryanto, M. Markum, V. Pratiwi, and C. Husadha, "Ecobrick sebagai Sarana Pengembangan Diri Berbasis Ecopreneurship di Sekolah Dasar,” DWIJA CENDEKIA J. Ris. Pedagog., vol. 3, no. 1, p. 93, 2019, doi: 10.20961/jdc.v3i1.34076.

[8] Z. T. Rony, "Generation y challenges in becoming innovative leaders at organization in the $21 \mathrm{st}$ century," Int. J. Recent Technol. Eng., vol. 8, no. 2 Special Issue 9, pp. 789-794, 2019, doi: 10.35940/ijrte.B1164.0982S919. 
[9] Z. Rony and S. Aryanto, "Coaching Competency as a Solution for Indonesian Headmaster of Elementary School in Disruption Era," 2020, doi: 10.4108/eai.13-2-2019.2286504.

[10] M. Schaper, "The essence of ecopreneurship," Greener Manag. Int., no. 38, pp. 26-30, 2002, doi: 10.9774/GLEAF.3062.2002.su.00004.

[11] S. Schaltegger, “A Framework for Ecopreneurship,” Greener Manag. Int., vol. 2002, no. 38, pp. 4558, 2014, doi: 10.9774/gleaf.3062.2002.su.00006.

[12] S. E. A. Dixon and A. Clifford, "Ecopreneurship - A new approach to managing the triple bottom line," J. Organ. Chang. Manag., vol. 20, no. 3, pp. 326-345, 2007, doi: $10.1108 / 09534810710740164$.

[13] V. A. N. Ariawan, N. T. Utami, and R. Rahman, "Peningkatan Keterampilan Membaca Pemahaman Siswa Sekolah Dasar Melalui Implementasi Model CIRC Berbantuan Media Cetak," al-Aulad J. Islam. Prim. Educ., vol. 1, no. 2, pp. 95-104, 2018, doi: 10.15575/al-aulad.vli2.3529.

[14] F. A. Rahman and V. S. Damaianti, "Model Multiliterasi Kritis Dalam Pembelajaran Siswa Sekolah Dasar," J. Pendidik. Dasar, vol. 10, no. 1, pp. 27-34, 2019, [Online]. Available: http://journal.unj.ac.id/unj/index.php/jpd/article/view/11140/7080.

[15] R. Rahman, A. W. Sakti, R. N. Widya, and R. Yugafiati, "Elementary Education Literacy in the Era of Industrial Revolution 4.0," vol. 257, no. Icollite 2018, pp. 190-193, 2019, doi: 10.2991/icollite18.2019.41.

[16] S. Aryanto and E. Syaodih, "Development of Ecopreneurship in Primary School," IJAEDU- Int. EJournal Adv. Educ., vol. III, no. 9, pp. 597-602, 2017, doi: 10.18768/ijaedu.370428. 